\title{
MONQAR EL SANAB-MONQAR EL RAML SILICA SAND, QARAT SOMARAH REGION, EGYPT: ECONOMIC POTENTIAL AND SOME FORM OF PROCESSING TECHNIQUES
}

\author{
Hassaan, M. M. ${ }^{1}$, Ali, H. I. ${ }^{2}$, Ramzy, O. E. ${ }^{1}$, Sakr, S. M. ${ }^{1,3}$ \\ 1- Faculty of Science, Al- Azhar University, \\ 2- ASCOM Company, Cairo, Egypt. \\ 3- Taibah University, Madinah
}

\begin{abstract}
Monqar El-Sanab - Monqar El-Raml area is located $50 \mathrm{~km}$ SSW El-Hammam city, Northern Western Desert between latitudes $30^{\circ} 26^{\prime} 30^{\prime \prime}$ and $30^{\circ} 20^{\prime} 00^{\prime \prime} \mathrm{N}$. and longitudes $29^{\circ} 09^{\prime \prime} 00^{\prime \prime}$ and $29^{\circ} 22^{\prime \prime} 30^{\prime \prime}$ E. The composite stratigraphic succession of the Early Miocene Moghra Formation includes exposed very compact and consolidated ferruginous sandstones, calcareous silica sand and silica sand beds $19.5 \mathrm{~m}$ thick and greyish black clay and shale bed $1.5 \mathrm{~m}$ thick at its top. Silica sand is essential raw materials for glassmaking, industrial, horticultural, leisure and foundry casting applications. The study aims at undertaking investigations on the silica sand geologic features, grain size, chemical composition, easy remove of deleterious impurities, together with the level of friable sand some required form of processing technique to conform very closely to the standard specifications, and consistency in quality suitable for economic applications. The silica sand beds are sited at the top of southwards moderate sloping to the base of the succession. The consolidated and very compact ferruginous sandstones comprise calcareous quartz arenite and ferruginous calcareous quartz arenite. Both consist chiefly of $>90 \%$ quartz, fine to coarse, rounded to sub-angular occasionally fractured grains ( $>95 \mathrm{wt}$. \% silica). The $\mathrm{SiO}_{2}$ discriminates three Grades I, II, III: $>98,<98->97,<97->95$ wt. \% and as well, $\mathrm{Al}_{2} \mathrm{O}_{3}$ and $\mathrm{Fe}_{2} \mathrm{O}_{3}$ contents: $0.35-0.14$, 1.71- 0.3; 0.8- 0.2, 2.3-1.71; and 1.84- 0.4, 2.3 - 1.71 wt. \% respectively. The 3 grades record highest wt. $\%$ of the size $<600 \mu \mathrm{m}->106 \mu \mathrm{m}$ to be considered suitable for upgrading the sand. Exceptional samples of Grades I, II exist where the sizes $>600 \mu \mathrm{m}$ possess high wt. $\%$ to recommend combination of these size classes $>600 \mu \mathrm{m}$ of the sand from the sites of such samples on exploitation. The washing of the sizes $<600 \mu \mathrm{m}->106 \mu \mathrm{m}$ produced sharp decrease of $\mathrm{Fe}_{2} \mathrm{O}_{3}, \mathrm{CaO}$ content of the three grades (times $0.39,0.32$, 0.18 and $0.46,0.35,0.016$ ). Loss on washing with water is $6.4,1.8,16.0 \mathrm{~kg} /$ ton and with 2 and $5 \% \mathrm{HCl}$ solution $6.4,1.8,16.0 \mathrm{~kg} /$ ton to be considered an approach of suitable upgrading.
\end{abstract}

Keywords: Qarat somarah, silica sand, physicochemical properties, upgrading techniques.

\section{INTRODUCTION}

Monqar El-Sanab - Monqar El-Raml area is sited between latitudes 30²6'30" and 30²0'00"N. and longitudes $29^{\circ} 09^{\prime \prime} 00^{\prime \prime}$ and 29 $22^{\circ} 30^{\prime \prime} \mathrm{E}$ (Fig. 1). It is located $50 \mathrm{~km}$ SSW El-Hammam city, Northern Western Desert. This district has been studied by several authors, of these Shata,1955; Said,1962; Segiev,1969; Abu Khadrah, 1973; Omara and Sanad, 1975; El-Khoraby,1985; Abu Zeid, 1984; Issawi et al., 1999, 2009; and Hassaan et al., 2019.

The studied area has witnessed wide-spread transgressions and regressions, partly combined with structural deformations and consequent depositional hiatuses during the Late Oligocene- Middle Miocene. There, the Early Miocene Moghra Formation nominated El Raml Formation at Monqar El-Raml area by Abu Zeid (1984) is overlain with unconformity by the Pliocene El-Hagef Formation (Issawi et al., op cit). The composite stratigraphic succession of the Early Miocene Moghra Formation at Qor El-Hellab, Monqar El- Sanab, and Monqar El-Raml after Hassaan et al.,( 2019) from base to top is very compact ferruginous sandstone reddish black hilly accumulations of altitude $10-20 \mathrm{~m}$, friable reddish yellowish ferruginous sand beds, alternating calcareous white sand, greyish black clay and shale at Qor El-Hellab, 
followed upward at Monqar El-Sanab by white calcareous silica sand bed $4.5 \mathrm{~m}$ thick, white silica sand bed $15 \mathrm{~m}$ thick and greyish black clay and shale bed $1.5 \mathrm{~m}$ thick at its top. The highest hilly accumulations is cut by highly ferruginous quartz veins filling two fault planes one is trending NW intersected by the other trending NE. The recorded silica sand beds of total thickness $19.5 \mathrm{~m}$ possess chief grain-size $<600$ $\mu \mathrm{m}->106 \mu \mathrm{m}$, rare deleterious impurities, no refractory minerals, $\mathrm{SiO}_{2}>95-98.8 \mathrm{wt} . \%, \mathrm{Al}_{2} \mathrm{O}_{3}<1.6-0.3$ wt.\%, $\mathrm{Fe}_{2} \mathrm{O}_{3}$ 2.3-0.3 wt.\% (Hassaan et al., 2019).

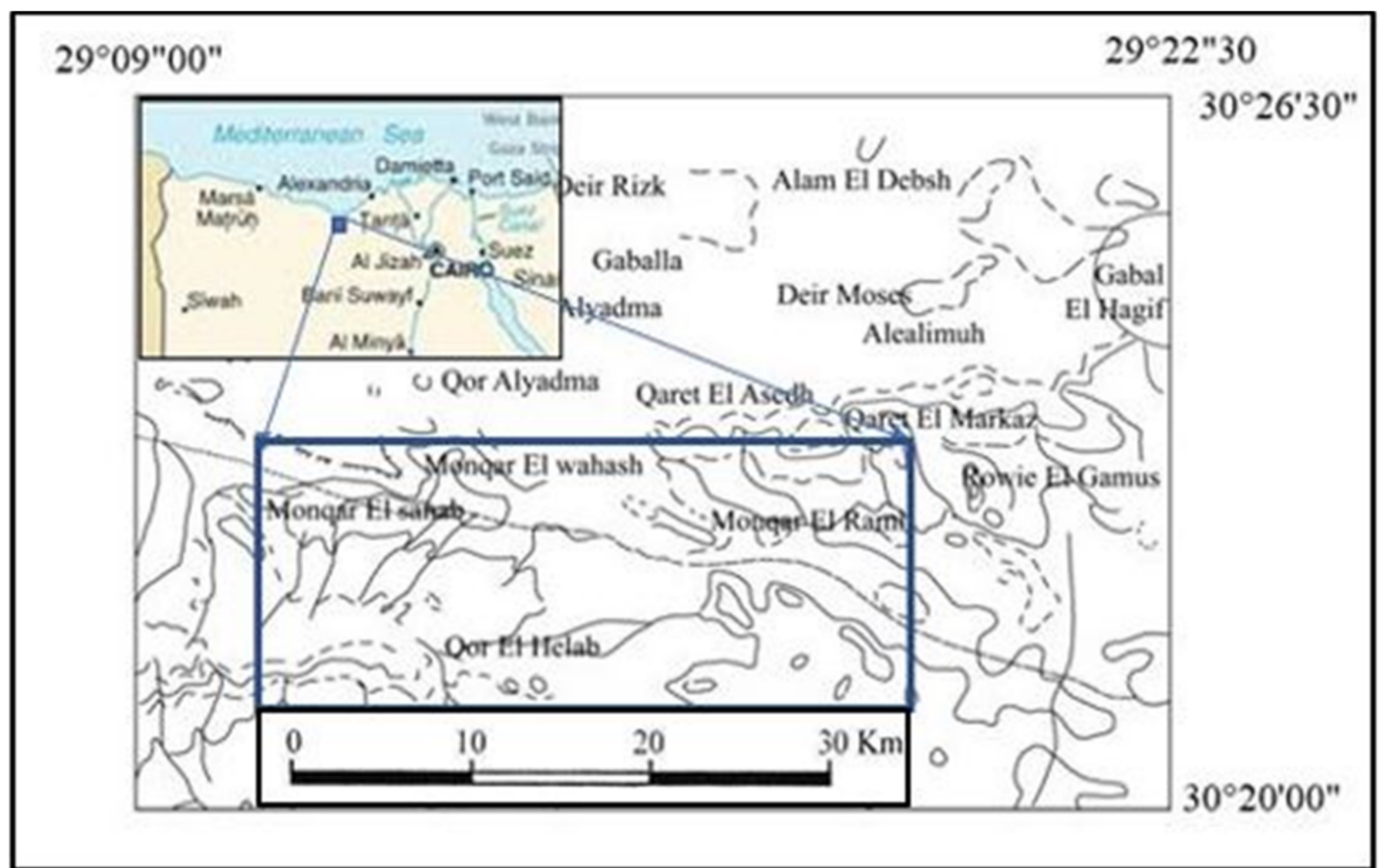

Fig.1: Part of Qarat Somarah topographic map showing location of Monqar El Sanab- Monqar El-Raml area, (From Conoco, 1987 with addition).

Silica sand is essential raw materials for glass making (accounted the highest of total sales) and a wide range of other industrial, horticultural and leisure applications, foundry casting for aerospace, military and precision automotive parts (sand of higher quality). Different grades of silica sand are usually not interchangeable in use. Silica sand, normally contains more than $95 \% \mathrm{SiO}_{2}$, are valued for a combination of factors viz; geologic setting, deleterious mineral impurities, physical properties and chemical constituents. They typically have a narrow grain-size generally in the range 0.5 to $0.1 \mathrm{~mm}$. For critical importance of most applications silica sands have to conform to very closely defined specifications, and consistency in quality. Particular uses often require such different combinations of properties that all of the sand resources almost require some form of processing technique to upgrade them into marketable form.

Consequently, the consistency of quality of the silica sand in the study area requires choice of required forms of processing technique to upgrade them into ultimate economic industrial forms.

\section{THE AIM OF THE STUDY}

In consequence, the present study aims at undertaking investigations on the detailed geologic features, chemical composition, inherent grain size, the easy removal of deleterious impurities (dust, halite, clay), together with the level of losses and some required forms of processing technique. Such studies concern whenever possible, upgrading the silica sand of the studied area to conform to the very closely defined standard specifications, and consistency in quality suitable for economic applications of white silica sand. 


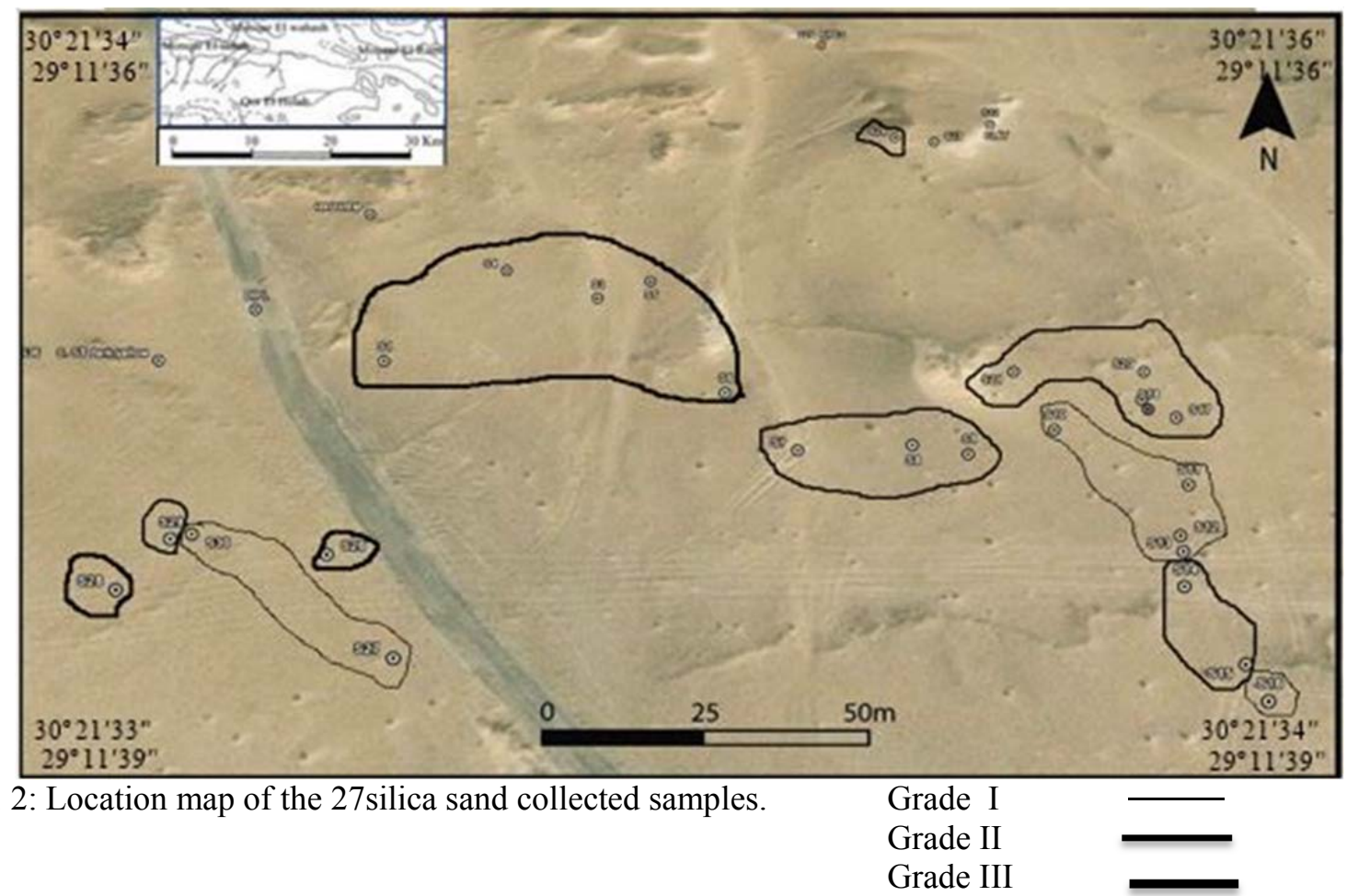

\section{METHODOLOGIES AND SOME FORM OF PROCESSING}

Particular uses of silica sand require combinations of studying geologic setting for easy mining, estimation of the dominant suitable grain size, determination of chemical composition, removal of impurities (clay, dust) and some form of processing to upgrade them into marketable form as follows:-

\section{Geologic Features}

a- Field study and sampling where 27 silica sand samples were collected (Fig. 2)

b- Petrographic investigation of 12 thin sections of the very compact reddish black sandstone and the colored calcareous sandstone.

c- Mineralogical investigation to record any deleterious mineral impurities.

\section{Chemical Grade}

a- Estimation of the contents of silica and other major oxides in 27 samples, due to their critical importance, in particular, silica (normally must be more than 95\%) for industrial uses of silica sand.

b- Use of the estimated contents to define the grade of the studied silica sand in relation to its site.

\section{Screen Analysis}

a- Screening using two sieves $600 \mu \mathrm{m}$ and $106 \mu \mathrm{m}$ of three composite silica sand samples weighing $2 \mathrm{~kg}$ prepared by weighing equal weight of each sample of every discriminated chemical grade to estimate the distribution of the grain sizes $>600 \mu \mathrm{m},<600 \mu \mathrm{m}->106 \mu \mathrm{m}$, and $<106 \mu \mathrm{m}$.

b- Estimation of the quantitative abundance of the grain-size $<600 \mu \mathrm{m}->106 \mu \mathrm{m}$, the typical critical of most applications of silica sand compared to the grain-sizes $>600 \mu \mathrm{m}$ and $<106 \mu \mathrm{m}$.

c- Chemical analysis of the three separated grain size classes $>600 \mu \mathrm{m},<600 \mu \mathrm{m}->106 \mu \mathrm{m}$ and $<106 \mu \mathrm{m}$.

\section{Washing for removal of deleterious impurities and level of losses}

a- Washing with shaking and decantation for several times of weighed $150 \mathrm{~g}$ of each grain size $<600 \mu \mathrm{m}$ $>106 \mu \mathrm{m}$ of the three prepared composite samples using normal water and estimation of losses. 
b- Washing with shaking and decantation for several times of weighed 50 gm. of grain size $<600 \mu \mathrm{m}$ $>106 \mu \mathrm{m}$ of each of the three composite samples by $2 \%$ followed by $5 \%$ dilute $\mathrm{HCl}$ acid solution for probable removal of iron oxide staining rare quartz grains and the other deleterious impurities.

c- Estimation of $\mathrm{SiO}_{2}$ content of the products of the steps $\mathrm{a}$ and $\mathrm{b}$ to detect the result of washing.

\section{RESULTS}

\section{Geologic Features}

The base of the Early Miocene Moghra Formation at Qor El-Hellab (nominated El Raml Formation at Monqar El-Raml area by Abu Zeid, 1984, (given in Hassaan et al., 2019) is represented by several very compact reddish black ferruginous sandstone hilly accumulations of altitude 10-20 m followed laterally from south northwards by ferruginous calcareous sandstone and calcareous silica sand, both are sited at the base of southwards gentle sloping of the other beds of the stratigraphic succession. The sand beds of white color 3-20 m thick cover an area extending from Gebel Hegif in the east to Dir El-Ressiw in the west via Qarat El-Markaz, Monqar El- Raml, Monqar El-Wahsh and Monqar El-Sanab. These white sands attain its maximum thickness at Monqar El-Sanab - Monqar El-Raml area and are covered with thin film of yellowish color.

The petrographic investigation of 12 thin sections of both sandstones indicates that they comprise ferruginous calcareous quartz arenite forming the very compact ferruginous sandstone, while the consolidated faint reddish yellow calcareous sand bed is calcareous quartz arenite. Mineralogically, the ferruginous calcareous quartz arenite consists mainly of $>90 \%$ quartz, fine to coarse- grained, rounded to angular (Fig. 3) occasionally fractured grains and rare euhedral plagioclase (Fig. 4a, c). Iron oxides are present as patches, filling the fractures of the quartz grains and coatings surrounding the margins of some quartz grains (Figs. 3a, b, and 4c). The quartz grains are embayed in micrite matrix (Fig. 4b). The micrite occurred during diagenesis.
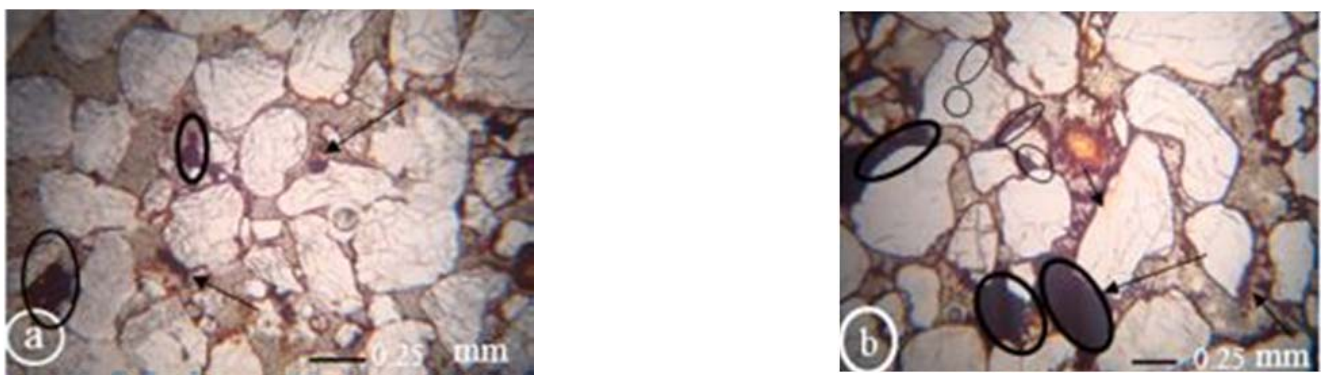

Fig. 3: a, b: Photomicrograph showing iron oxide patches or lining fractures in quartz grains and as rims of quartz grains, S. No. 25, X.N.
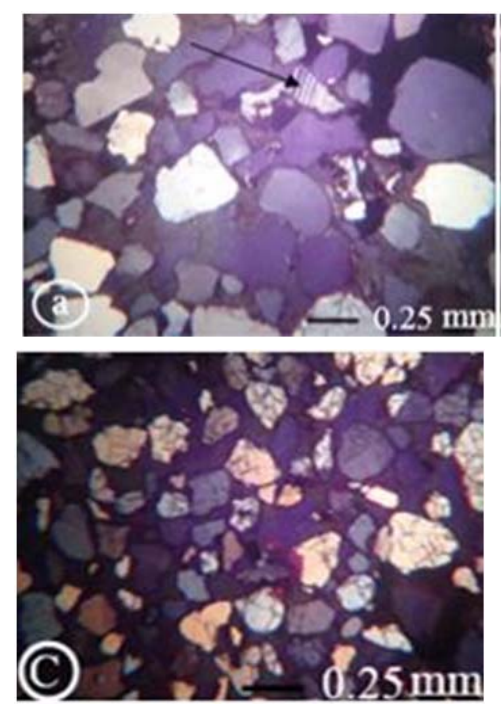

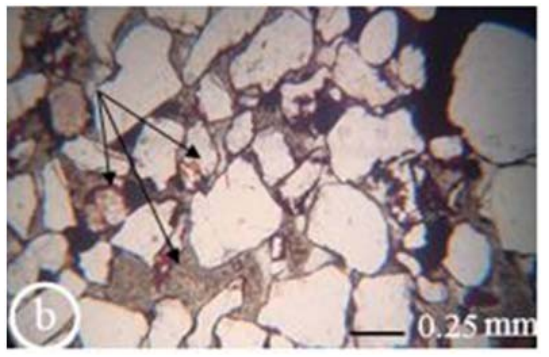

Fig. 4: Photomicrographs showing a: fine to coarse grained, sub-rounded to sub - angular quartz and plagioclase crystals. S. No 39, ppl, b: the embayed quartz grains. S. No 39, ppl, c: quartz grains fractured in the studied samples, S. No 48, 49 and 50 PPL. 
The calcareous quartz arenite is texturally classified as sand $99.9 \%$ and $0.1 \%$ muddy sand. The silica sand constituents are $0.24-0.21 \%$ heavy minerals and $99.86-98.89 \%$ light minerals chiefly quartz and rare alkali feldspars. The light minerals are composed of $>95 \%$ mono-crystalline quartz grains of medium size, fractured, rounded to sub- rounded occasionally sub-angular (Figs. 5a, b) cemented by matrix of micrite (Fig. 6b). The accessories are euhedral plagioclase (Fig. 5c), short thin prismatic zircon crystals (Fig. 6c) and rounded glauconite grains of medium size (Fig. 6a). Iron oxides are occasionally present as patches, lining the fractures and coating the quartz grains (Fig. 6b). Magnetite, rutile, zircon, glauconite, hematite, staurolite olivine and no chromite are recorded in both microfacies and unrecorded in the silica sand beds (Hassaan et al., 2019).

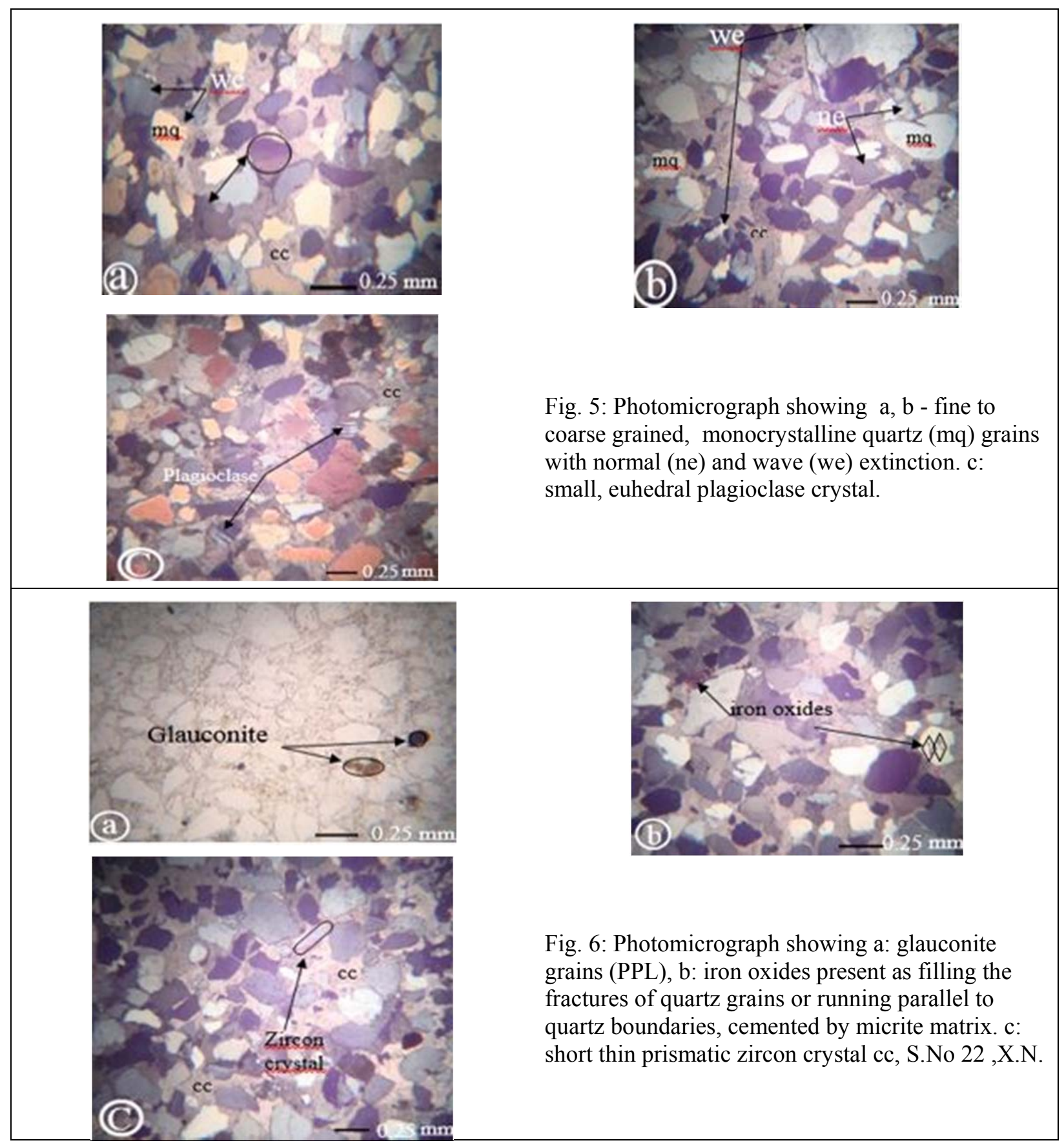

Hassaan et al., (op.cite) recorded several geologic, sedimentological, mineralogical and geochemical points of evidence beside the Maryut Pumice recorded in the Building Materials map (1998) expressing 
Hassaan, et al

action of tectonic events developed rifts, basins, sedimentation in mixed river/marine water, and volcanic activities associated with hydrothermal exhalation fluids. According to these authors, the Northern Western Desert district, as a whole, was subjected during the Late Oligocene- Early Miocene to tectonic events and fragmentation phases during the eastwards progressive propagation of West Gondwana in North Africa from Morocco, Algeria, Tunisia to be ended by rifting and birth of ocean; the Red Sea.

According to Hassaan et al., (op. cite), the Early Miocene sand beds represent single stream sediments, occasionally mixed from various provenances deposited in moderate energy multiple riverine /aeolian environment with flood action, calcareous marine influence, long distance transportation, variable water turbulence and velocity of current of deposition of the shallow marine/agitated fluvial sediments of inland facies controlled by slopes of river beds in rifting basins considered by Issawi et al., $(1999,2009)$ from Late Oligocene till Early Miocene (from Chattian, ca. 28.5Ma- top of Messinian, ca. 5.33Ma).

\section{Effective Chemical Components}

A total of 27 chemical analyses of the major oxides constituting the white sand silica shown in Table (1) indicate that $\mathrm{SiO}_{2}$ content ranges from 98.8 to 95 wt., $\%, \mathrm{Al}_{2} \mathrm{O}_{3}$ from 0.9 to 0.2 wt., $\%$ and $\mathrm{Fe}_{2} \mathrm{O}_{3}$ from 1.71 to 0.3 wt., \% except three samples for both. The ranges of the three oxides point to that the studied silica sand requires undertaking some form of processing technique to upgrade them into marketable form.

Table 1-Chemical Composition of the Collected Silica Sand Samples

\begin{tabular}{|c|c|c|c|c|c|c|c|c|c|}
\hline \multirow{2}{*}{ S. No. } & \multicolumn{9}{|c|}{ Chemical Analysis } \\
\cline { 2 - 11 } & $\mathrm{SiO}_{2}$ & $\mathrm{Al}_{2} \mathrm{O}_{3}$ & $\mathrm{Fe}_{2} \mathrm{O}_{3}$ & $\mathrm{CaO}$ & $\mathrm{MgO}$ & $\mathrm{SO}_{3}$ & $\mathrm{~K}_{2} \mathrm{O}$ & $\mathrm{Na}_{2} \mathrm{O}$ & $\mathrm{Cl}$ \\
\hline 1 & 95.01 & 1.5 & 2.01 & 0.10 & 0.23 & 0.25 & 0.21 & 0.47 & 0.19 \\
\hline 2 & 95.2 & 1.6 & 2.03 & 0.13 & BLD & 0.28 & 0.25 & 0.37 & 0.17 \\
\hline 3 & 96.6 & 0.88 & 1.90 & BLD & BLD & 0.13 & 0.07 & 0.27 & 0.19 \\
\hline 4 & 94.49 & 1.85 & 2.03 & BLD & BLD & 0.13 & 0.27 & 0.90 & 0.34 \\
\hline 5 & 96.32 & 0.85 & 1.93 & 0.21 & BLD & 0.24 & 0.09 & 0.20 & 0.15 \\
\hline 6 & 96.62 & 0.83 & 1.71 & 0.10 & BLD & 0.27 & 0.09 & 0.23 & 0.15 \\
\hline 7 & 97.61 & 0.27 & 1.66 & 0.01 & BLD & 0.23 & 0.00 & 0.08 & 0.15 \\
\hline 8 & 97.31 & 0.49 & 1.43 & BLD & 0.33 & 0.15 & 0.01 & 0.13 & 0.15 \\
\hline 9 & 97.46 & 0.41 & 1.69 & BLD & BLD & 0.17 & 0.00 & 0.11 & 0.15 \\
\hline 10 & 98.68 & 0.36 & 0.32 & 0.20 & BLD & 0.13 & 0.00 & 0.14 & 0.18 \\
\hline 11 & 98.20 & 0.12 & 1.36 & BLD & BLD & 0.14 & 0.00 & 0.03 & 0.15 \\
\hline 12 & 98.53 & $\mathrm{BLD}$ & 1.27 & BLD & BLD & 0.05 & 0.00 & 0.00 & 0.14 \\
\hline 13 & 98.60 & $\mathrm{BLD}$ & 1.19 & BLD & BLD & 0.07 & 0.00 & 0.00 & 0.15 \\
\hline 14 & 97.70 & 0.17 & 1.27 & BLD & BLD & 0.59 & 0.13 & 0.00 & 0.15 \\
\hline 15 & 97.16 & 0.77 & 1.41 & 0.13 & BLD & 0.12 & 0.07 & 0.17 & 0.16 \\
\hline 16 & 98.04 & 0.23 & 1.33 & BLD & BLD & 0.21 & 0.00 & 0.05 & 0.15 \\
\hline 17 & 97.70 & 0.58 & 1.23 & BLD & BLD & 0.13 & 0.04 & 0.16 & 0.16 \\
\hline 18 & 97.38 & 0.60 & 1.42 & 0.03 & BLD & 0.18 & 0.05 & 0.16 & 0.16 \\
\hline 19 & 97.19 & 0.90 & 1.35 & BLD & BLD & 0.07 & 0.10 & 0.24 & 0.16 \\
\hline 20 & 97.59 & 0.59 & 1.34 & 0.22 & BLD & 0.07 & 0.01 & 0.01 & 0.16 \\
\hline 21 & 97.31 & 0.71 & 1.41 & 0.03 & BLD & 0.13 & 0.05 & 0.20 & 0.16 \\
\hline 24 & 97.59 & 0.41 & 1.31 & 0.14 & BLD & 0.32 & BLD & 0.07 & 0.16 \\
\hline 26 & 96.70 & 0.44 & 1.77 & 0.32 & BLD & 0.50 & BLD & 0.10 & 0.16 \\
\hline 27 & 98.05 & 0.14 & 1.53 & 0.00 & BLD & 0.14 & BLD & 0.00 & 0.15 \\
\hline 28 & 96.26 & 0.73 & 2.30 & 0.13 & BLD & 0.26 & 0.03 & 0.14 & 0.16 \\
\hline 29 & 97.60 & 0.20 & 1.56 & 0.06 & BLD & 0.36 & BLD & 0.07 & 0.16 \\
\hline 30 & 98.13 & 0.15 & 1.31 & 0.09 & BLD & 0.14 & BLD & 0.03 & 0.15 \\
\hline $\mathrm{BLD}$ & -8.35 & & & & & \\
\hline
\end{tabular}

BLD - Beyond Limit of Detection of the applied XRF apparatus. 


\section{Monqar El Sanab-Monqar El Raml silica sand, Qarat Somarah region}

The $\mathrm{SiO}_{2}, \mathrm{Al}_{2} \mathrm{O}_{3}, \mathrm{Fe}_{2} \mathrm{O}_{3}$ contents discriminate three Grades I, II, III given in Table 2 as follows:-
Grade I
$\mathrm{SiO}_{2}>98$ wt. \%
7 samples
Grade II
$\mathrm{SiO}_{2}<98$ wt. \% - > 97 wt. \% 12 samples
Grade III
$\mathrm{SiO}_{2}<97$ wt. $\%$ - > 95 wt. \% 8 samples.

Also, the three Grades I, II, III are distinguished from each other by $\mathrm{Al} 2 \mathrm{O} 3$ and Fe2O3 contents as follows: -

Grade I

$\mathrm{Al}_{2} \mathrm{O}_{3}$ from 0.35 to 0.14 wt. \% averaging 0.14 wt. \%.

$\mathrm{Fe}_{2} \mathrm{O}_{3}$ from 1.71 to $0.3 \mathrm{wt} \%$ averaging 1.19 wt. \%.

Grade II

$\mathrm{Al}_{2} \mathrm{O}_{3}$ from 0.8 to $0.2 \mathrm{wt}$. \% averaging $0.54 \mathrm{wt}$. $\%$.

Grade III

$\mathrm{Fe}_{2} \mathrm{O}_{3}$ from 2.3 to 1.71 wt. \% averaging 1.42 wt. \%.

$\mathrm{Al}_{2} \mathrm{O}_{3}$ from 1.84 to 0.4 wt. $\%$ averaging 1.09 wt. $\%$.

$\mathrm{Fe}_{2} \mathrm{O}_{3}$ from 2.3 to 1.71 wt. \% averaging 1.96 wt. \%.

Table 2- The Grades of the silica sand samples due to silica content

\begin{tabular}{|c|c|c|c|c|c|c|c|c|}
\hline \multirow{2}{*}{ S. No. } & \multicolumn{7}{|c|}{ Chemical Analysis in wt., $\%$} & \multirow{2}{*}{$\begin{array}{r}\text { Grade } \\
\mathrm{SiO}_{2} \text { in wt. } \%\end{array}$} \\
\hline & $\mathrm{SiO}_{2}$ & $\mathrm{Al}_{2} \mathrm{O}_{3}$ & $\mathrm{Fe}_{2} \mathrm{O}_{3}$ & $\mathrm{CaO}$ & $\mathrm{MgO}$ & $\mathrm{SO}_{3}$ & $\mathrm{~K}_{2} \mathrm{O}$ & \\
\hline 10 & 98.70 & 0.35 & 0.32 & 0.20 & 0.00 & 0.13 & 0.00 & \multirow{7}{*}{ Grade I $>98$} \\
\hline 11 & 98.20 & 0.12 & 1.36 & 0.00 & 0.00 & 0.14 & 0.00 & \\
\hline 12 & 98.52 & B.Y.D & 1.27 & 0.00 & 0.00 & 0.05 & 0.00 & \\
\hline 13 & 98.60 & B.Y.D & 1.19 & 0.00 & 0.00 & 0.07 & 0.00 & \\
\hline 16 & 98.04 & 0.22 & 1.33 & 0.00 & 0.00 & 0.21 & 0.00 & \\
\hline 27 & 98.05 & 0.14 & 1.53 & 0.00 & 0.00 & 0.14 & 0.00 & \\
\hline 30 & 98.13 & 0.15 & 1.31 & 0.09 & 0.00 & 0.14 & 0.00 & \\
\hline 7 & 97.60 & 0.27 & 1.66 & 0.01 & 0.00 & 0.23 & 0.00 & \multirow{12}{*}{ Grade II $<98->97$} \\
\hline 8 & 97.31 & 0.50 & 1.43 & 0.00 & 0.33 & 0.15 & 0.01 & \\
\hline 9 & 97.50 & 0.40 & 1.69 & 0.00 & 0.00 & 0.17 & 0.00 & \\
\hline 14 & 97.70 & 0.17 & 1.27 & 0.00 & 0.00 & 0.59 & 0.13 & \\
\hline 15 & 97.16 & 0.80 & 1.41 & 0.13 & 0.00 & 0.12 & 0.07 & \\
\hline 17 & 97.70 & 0.60 & 1.23 & 0.00 & 0.00 & 0.13 & 0.04 & \\
\hline 18 & 97.40 & 0.60 & 1.42 & 0.03 & 0.00 & 0.18 & 0.05 & \\
\hline 19 & 97.20 & 0.90 & 1.35 & 0.00 & 0.00 & 0.07 & 0.10 & \\
\hline 20 & 97.60 & 0.60 & 1.34 & 0.22 & 0.00 & 0.07 & 0.01 & \\
\hline 21 & 97.30 & 0.71 & 1.41 & 0.03 & 0.00 & 0.13 & 0.05 & \\
\hline 24 & 97.60 & 0.41 & 1.31 & 0.14 & 0.00 & 0.32 & 0.00 & \\
\hline 29 & 97.60 & 0.20 & 1.56 & 0.06 & 0.00 & 0.36 & 0.00 & \\
\hline 1 & 95.01 & 1.5 & 2.01 & 0.10 & 0.23 & 0.25 & 0.21 & \multirow{8}{*}{ Grade III $<97$ - >95 } \\
\hline 2 & 95.2 & 1.60 & 2.03 & 0.13 & 0.00 & 0.28 & 0.25 & \\
\hline 3 & 96.6 & 0.90 & 1.90 & 0.00 & 0.00 & 0.13 & 0.07 & \\
\hline 4 & 94.50 & 1.84 & 2.03 & 0.00 & 0.00 & 0.13 & 0.27 & \\
\hline 5 & 96.32 & 0.85 & 1.93 & 0.21 & 0.00 & 0.24 & 0.09 & \\
\hline 6 & 96.61 & 0.82 & 1.71 & 0.10 & 0.00 & 0.27 & 0.09 & \\
\hline 26 & 96.70 & 0.44 & 1.77 & 0.32 & 0.00 & 0.50 & 0.00 & \\
\hline 28 & 96.30 & 0.73 & 2.30 & 0.13 & 0.00 & 0.26 & 0.03 & \\
\hline
\end{tabular}

BLD - Beyond Limit of Detection of the applied XRF apparatus

It is obvious that the three grades require some form of processing techniques to remove iron oxide and clay minerals whenever possible, separation of heavy minerals, and whatever required, removal of each of the grain size $>600 \mu \mathrm{m},<106 \mu \mathrm{m}$ and dust to match with the standard specification values $\left(\mathrm{Fe}_{2} \mathrm{O}_{3}<0.03\right.$ wt. \%). Meanwhile, Grade III requires removal of the grain size $(<0.106 \mu \mathrm{m})$ by screening and removal 
of dust by washing with water to minimize $\mathrm{A} 12 \mathrm{O} 3$ content to the standard specification value $(<0.6 \mathrm{wt}$. $\%)$.

The distribution of the six grain size classes (Table 3) show that Grade I and II sand except that represented by S. No. 12, 13 and S. No.14 respectively record high weight percentage of both grain size classes $<600 \mu \mathrm{m}->106 \mu \mathrm{m}$ to be recommended for industrial application. The grain size classes $>600 \mu \mathrm{m}$ for the silica sand represented by samples 12,13 of Grade I and 14 of Grade II possess high weight percentage $49.98,33.82$ and $52.31 \mathrm{wt}$. \% respectively recommending combination of these grain size classes of the sand of such sites whenever possible on application in industry.

Table 3- Distribution of the six screened grain size classes.

\begin{tabular}{|c|c|c|c|c|c|c|c|}
\hline \multirow{2}{*}{$\begin{array}{l}\text { Sample } \\
\text { No. }\end{array}$} & $\mathrm{SiO}_{2}$ (in wt. \%) & \multicolumn{7}{|c|}{ Grain size classes in wt. \% } \\
\cline { 2 - 8 } & Bulk sample & $\begin{array}{c}>850 \\
\mu \mathrm{m}\end{array}$ & $\begin{array}{c}<850->710 \\
\mu \mathrm{m}\end{array}$ & $\begin{array}{c}<710->600 \\
\mu \mathrm{m}\end{array}$ & $\begin{array}{c}<600- \\
>300 \mu \mathrm{m}\end{array}$ & $\begin{array}{c}<300-> \\
106 \mu \mathrm{m}\end{array}$ & $\begin{array}{c}<106 \\
\mu \mathrm{m}\end{array}$ \\
\hline 1 & 95.01 & 0.65 & 0.30 & 0.50 & 8.89 & 85.78 & 3.59 \\
\hline 2 & 95.2 & & & & & & \\
\hline 3 & 96.6 & 0.03 & 0.01 & 0.05 & 12.21 & 85.18 & 2.09 \\
\hline 4 & 94.49 & 0.14 & 0.05 & 0.06 & 4.95 & 88.87 & 5.09 \\
\hline 5 & 96.32 & 1.71 & 0.25 & 0.57 & 27.07 & 67.75 & 2.15 \\
\hline 6 & 96.62 & 0.40 & 0.13 & 0.19 & 22.25 & 75.74 & 1.27 \\
\hline 7 & 97.61 & 0.95 & 0.43 & 0.90 & 49.63 & 46.80 & 0.73 \\
\hline 8 & 97.31 & 1.31 & 0.76 & 1.30 & 49.95 & 45.84 & 0.34 \\
\hline 9 & 97.46 & 0.52 & 0.16 & 0.35 & 39.88 & 57.93 & 0.68 \\
\hline 10 & 98.68 & 0.47 & 0.41 & 0.76 & 54.14 & 43.75 & 0.10 \\
\hline 11 & 98.20 & 0.83 & 0.69 & 1.52 & 79.04 & 17.56 & 0.13 \\
\hline 12 & 98.53 & 17.82 & 13.43 & 18.73 & 47.01 & 2.08 & 0.03 \\
\hline 13 & 98.60 & 7.58 & 10.11 & 16.43 & 60.96 & 4.28 & 0.14 \\
\hline 14 & 97.70 & 32.43 & 9.78 & 10.10 & 39.96 & 7.15 & 0.10 \\
\hline 15 & 97.16 & 0.10 & 0.01 & 0.07 & 30.50 & 68.10 & 0.32 \\
\hline 16 & 98.04 & 0.19 & 0.02 & 0.11 & 70.79 & 28.21 & 0.20 \\
\hline 17 & 97.70 & 0.85 & 0.70 & 1.64 & 46.65 & 49.61 & 0.43 \\
\hline 18 & 97.38 & 1.56 & 1.00 & 1.80 & 47.44 & 47.66 & 0.10 \\
\hline 19 & 97.19 & 0.10 & 0.01 & 0.10 & 37.40 & 61.51 & 0.28 \\
\hline 20 & 97.59 & 2.19 & 1.77 & 3.17 & 41.59 & 50.68 & 0.38 \\
\hline 21 & 97.31 & 0.48 & 0.17 & 0.34 & 25.80 & 72.43 & 0.47 \\
\hline 24 & 97.59 & 1.15 & 0.83 & 1.85 & 56.09 & 38.90 & 0.80 \\
\hline 26 & 96.70 & 0.48 & 0.14 & 0.38 & 47.62 & 49.82 & 0.97 \\
\hline 27 & 98.05 & 5.01 & 4.76 & 11.75 & 58.68 & 18.40 & 1.02 \\
\hline 28 & 96.26 & 0.87 & 0.13 & 0.14 & 13.62 & 83.36 & 1.87 \\
\hline 29 & 97.60 & 5.61 & 2.00 & 4.00 & 64.38 & 22.47 & 0.81 \\
\hline 30 & 98.13 & 4.75 & 3.20 & 5.07 & 56.10 & 29.90 & 0.70 \\
\hline
\end{tabular}

\section{Results of Screen Analysis}

\section{Screening of composite samples of every grade}

The results of chemical analysis of the grain size classes $<600 \mu \mathrm{m}->106 \mu \mathrm{m}$ of two screened samples which represent Grade II and Grade III are given in Table (4). The results show the increase of silica and relative decrease of the contents of $\mathrm{Fe}_{2} \mathrm{O}_{3}, \mathrm{TiO}_{2}, \mathrm{Al}_{2} \mathrm{O}_{3}, \mathrm{CaO}$ and $\mathrm{K}_{2} \mathrm{O}$ pointing to probable upgrading the two grades. 


\section{Monqar El Sanab-Monqar El Raml silica sand, Qarat Somarah region}

Table 4- Chemical analysis of the grain sizes $<600 \mu \mathrm{m}->106 \mu \mathrm{m}$ of two samples represent Grade II and Grade III.

\begin{tabular}{|l|l|l|l|l|}
\hline \multirow{3}{*}{ Major Oxides } & \multicolumn{2}{|l|}{$\begin{array}{l}\text { Complete Chemical } \\
\text { Composition of Samples No. }\end{array}$} & $\begin{array}{l}\text { Chemical Composition of the Grain Size } \\
<600 \mu \mathrm{m}->106 \mu \mathrm{m} \text { of Samples No. }\end{array}$ \\
\cline { 2 - 5 } & 11 Grade II & 28 GradeIII & 11 Grade II & 28 GradeIII \\
\hline $\mathrm{SiO}_{2}$ & $97.85 \%$ & $93.17 \%$ & $98.20 \%$ & $96.20 \%$ \\
\hline $\mathrm{Fe}_{2} \mathrm{O}_{3}$ & $0.19 \%$ & $1.05 \%$ & $0.18 \%$ & $0.75 \%$ \\
\hline $\mathrm{Al}_{2} \mathrm{O}_{3}$ & $1.05 \%$ & $2.09 \%$ & $0.80 \%$ & $1.19 \%$ \\
\hline $\mathrm{TiO}_{2}$ & $0.11 \%$ & $1.06 \%$ & $0.10 \%$ & $0.71 \%$ \\
\hline $\mathrm{CaO}$ & $0.01 \%$ & $0.03 \%$ & $0.40 \%$ & $0.63 \%$ \\
\hline $\mathrm{K}_{2} \mathrm{O}$ & $0.29 \%$ & $0.42 \%$ & $0.30 \%$ & $0.36 \%$ \\
\hline
\end{tabular}

The obtained results of screening samples of each chemical grade indicate the distribution of the grain size classes $>600 \mu \mathrm{m},<600 \mu \mathrm{m}->106 \mu \mathrm{m}$, and $<106 \mu \mathrm{m}$ and given in Table (5). It is seen that the grain size $<600 \mu \mathrm{m}->106 \mu \mathrm{m}$ is the most dominant. However, four samples from the seven of Grade I show abundant weight percentage of the grain size classes $>600 \mu \mathrm{m}$ ranging from 43.98 to 13.02 wt., \%. Only three samples 12, 13 of Grade I and 14 of Grade II recorded abundance of this grain size ranging from 52.31 to 11.61 wt., \%, while these grain size classes of the eight samples of Grade III do not show exceptional values. Therefore, the calculated averages of the three grain size classes given in Table (6) must be considered on application of this silica sand in various industries.

Table 5: The weight percentages of the grain size classes $>600 \mu \mathrm{m},<600 \mu \mathrm{m}->106 \mu \mathrm{m},<106 \mu \mathrm{m}$ of the samples of each Grade

\begin{tabular}{|c|c|c|c|c|c|}
\hline \multirow[b]{2}{*}{ Sample No. } & \multicolumn{3}{|c|}{ Sieve Analysis in wt.,\% } & \multirow[b]{2}{*}{ Total } & \multirow[b]{2}{*}{ Chemical Grade } \\
\hline & $>600 \mu \mathrm{m}$ & $\begin{array}{l}<600 \mu \mathrm{m}- \\
>106 \mu \mathrm{m}\end{array}$ & $<106 \mu \mathrm{m}$ & & \\
\hline 10 & 1.64 & 97.89 & 0.10 & 99.63 & \multirow{7}{*}{ Grade I } \\
\hline 11 & 3.04 & 96.60 & 0.13 & 99.77 & \\
\hline 12 & 49.98 & 49.09 & 0.03 & 99.10 & \\
\hline 13 & 34.12 & 65.24 & 0.14 & 99.50 & \\
\hline 16 & 0.32 & 99.00 & 0.20 & 99.52 & \\
\hline 27 & 21.52 & 77.08 & 1.02 & 99.62 & \\
\hline 30 & 13.02 & 86.00 & 0.70 & 99.72 & \\
\hline 7 & 2.28 & 96.43 & 0.73 & 99.44 & \multirow{12}{*}{ Grade II } \\
\hline 8 & 3.37 & 95.79 & 0.34 & 99.50 & \\
\hline 9 & 1.03 & 97.81 & 0.68 & 99.52 & \\
\hline 14 & 52.31 & 47.11 & 0.10 & 99.52 & \\
\hline 15 & 0.18 & 98.60 & 0.32 & 99.10 & \\
\hline 17 & 3.19 & 96.26 & 0.43 & 99.88 & \\
\hline 18 & 4.36 & 95.10 & 0.10 & 99.56 & \\
\hline 19 & 0.21 & 98.91 & 0.28 & 99.40 & \\
\hline 20 & 7.13 & 92.27 & 0.38 & 99.78 & \\
\hline 21 & 0.99 & 98.23 & 0.47 & 99.69 & \\
\hline 24 & 3.83 & 94.99 & 0.80 & 99.62 & \\
\hline 29 & 11.61 & 86.85 & 0.81 & 99.27 & \\
\hline 1 & 1.45 & 94.67 & 3.59 & 99.71 & \multirow{8}{*}{ Grade III } \\
\hline 2 & 1.20 & 94.30 & 4.10 & 99.60 & \\
\hline 3 & 0.09 & 97.39 & 2.09 & 99.57 & \\
\hline 4 & 0.25 & 93.82 & 5.09 & 99.16 & \\
\hline 5 & 2.53 & 94.82 & 2.15 & 99.50 & \\
\hline 6 & 0.72 & 97.99 & 1.27 & 99.98 & \\
\hline 26 & 1.00 & 97.44 & 0.97 & 99.41 & \\
\hline 28 & 1.14 & 96.98 & 1.87 & 99.99 & \\
\hline
\end{tabular}


Hassaan, et al

Table 6- The averages of the weight percentages of the three grain size classes

\begin{tabular}{|c|c|c|c|}
\hline \multicolumn{3}{|c|}{ Sieve Analysis Wt.\% } & $\begin{array}{c}\text { Chemical } \\
\text { Specification }\end{array}$ \\
\hline$>600 \mu \mathrm{m}$ & $<600 \mu \mathrm{m}->106 \mu \mathrm{m}$ & $<106 \mu \mathrm{m}$ & Grade I \\
\hline 17.66 & 81.56 & 0.33 & Grade II \\
\hline 7.54 & 91.53 & 0.45 & Grade III \\
\hline 1.08 & 95.70 & 2.83 & \\
\hline
\end{tabular}

\section{Washing for Removal of Deleterious Impurities}

\section{Washing with shaking and decantation with normal water}

Weighed $50 \mathrm{~g}$ of the grain size classes $<600 \mu \mathrm{m}->106 \mu \mathrm{m}$ of each of the three prepared composite samples is washed using normal water with shaking, settling and decantation for several times. The weight of the washed samples of the three grades I, II, III are 49.68, 49.91, $49.20 \mathrm{~g}$ respectively pointing to that the loss $/ 50 \mathrm{~g}$ on washing is $0.32,0.09,0.8 \mathrm{~g}$, and loss is $6.4,1.8,16.0 \mathrm{~kg} /$ ton respectively.

The chemical analyses of the grain size $<600 \mu \mathrm{m}->106 \mu \mathrm{m}$ of each of the three composite samples of the three grades after washing compared to the calculated averages (Table 8) show obvious decrease of silica and alumina contents of each of the Grades I and II and no practical change of silica content of Grade III. This is referred to the exceptional high content of the grain size $>600 \mu \mathrm{m}$ in some samples of each of both grades I and II. In consequence, detailed grid pattern of sampling is recommended before exploitation. The sharp decrease of iron oxide and $\mathrm{CaO}$ contents of the three grades I, II, III after washing (times $0.39,0.32,0.18$ and $0.46,0.35,0.016$ respectively) can be considered valuable to conform to the standard values (Table 9) and to be suitable approach for upgrading.

Table 7- Chemical analyses of the three grain sizes $<600$ - >106 $\mu \mathrm{m}$ composite samples after washing and their calculated averages.

\begin{tabular}{|l|c|c|c|}
\hline \multirow{2}{*}{ Major Oxides } & \multicolumn{3}{|c|}{ Complete Analysis (after) } \\
\cline { 2 - 4 } & Grade I & Grade II & Grade III \\
\hline $\mathrm{SiO}_{2}$ & $93.58 \%$ & $94.77 \%$ & $95.28 \%$ \\
\hline $\mathrm{Fe}_{2} \mathrm{O}_{3}$ & $0.46 \%$ & $0.48 \%$ & $0.49 \%$ \\
\hline $\mathrm{Al}_{2} \mathrm{O}_{3}$ & $3.13 \%$ & $2.30 \%$ & $2.05 \%$ \\
\hline $\mathrm{TiO}_{2}$ & $0.26 \%$ & $0.40 \%$ & $0.30 \%$ \\
\hline $\mathrm{CaO}$ & 0.0190 & 0.0180 & 0.017 \\
\hline $\mathrm{K}_{2} \mathrm{O}$ & $0.76 \%$ & $0.53 \%$ & $0.50 \%$ \\
\hline
\end{tabular}

Table 8- The calculated averages of the chemical analyses of the three grades.

\begin{tabular}{|l|c|c|c|}
\hline \multirow{2}{*}{ Major Oxides } & \multicolumn{3}{|c|}{ Calculated Averages } \\
\cline { 2 - 4 } & Grade I & Grade II & Grade III \\
\hline $\mathrm{SiO}_{2}$ & $98.32 \%$ & $97.47 \%$ & $95 . \%$ \\
\hline $\mathrm{Fe}_{2} \mathrm{O}_{3}$ & $1.18 \%$ & $1.42 \%$ & $2.67 \%$ \\
\hline $\mathrm{Al}_{2} \mathrm{O}_{3}$ & $0.19 \%$ & $0.51 \%$ & $1.08 \%$ \\
\hline $\mathrm{TiO}_{2}$ & n.d. & n. d. & n. d. \\
\hline $\mathrm{CaO}$ & $0.041 \%$ & 0.051 & 0.14 \\
\hline $\mathrm{K}_{2} \mathrm{O}$ & BLD & $0.038 \%$ & $0.12 \%$ \\
\hline
\end{tabular}

\section{Washing with shaking and decantation after settling of the sand size by $2 \%$ and $5 \%$ dilute $\mathrm{HCl}$ acid solution.}

Each weighed $50 \mathrm{~g}$ of the grain size $<600->106 \mu \mathrm{m}$ of the three prepared composite samples is washed by $2 \%$ followed by $5 \%$ dilute solution of $\mathrm{HCl}$ acid with continuous shaking and decantation after settling of the sand size several times. The weight of the washed samples of the three grades I, II, III are 49.01, 49.51 and $48.81 \mathrm{~g}$ respectively pointing to that the loss $/ 50 \mathrm{~g}$ on washing $0.99,0.49,1.19 \mathrm{~g}$, consequently loss $/$ ton is $19.8,9.8,23.8 \mathrm{~kg} /$ ton respectively. 
Table 9- Chemical analyses of the three composite grain size classes $<600->106 \mu \mathrm{m}$ samples after washing with dil. $\mathrm{HCl}$ solution and the calculated averages, (see Table 8).

\begin{tabular}{|c|c|c|c|}
\hline \multirow{2}{*}{ Major Oxides } & \multicolumn{3}{|c|}{ Complete Analysis (after) } \\
\cline { 2 - 4 } & Grade I & Grade II & Grade III \\
\hline $\mathrm{SiO}_{2}$ & $95.61 \%$ & $96.21 \%$ & $95.55 \%$ \\
\hline $\mathrm{Fe}_{2} \mathrm{O}_{3}$ & $0.12 \%$ & $0.36 \%$ & $0.31 \%$ \\
\hline $\mathrm{Al}_{2} \mathrm{O}_{3}$ & $2.09 \%$ & $1.98 \%$ & $1.46 \%$ \\
\hline $\mathrm{TiO}_{2}$ & $0.15 \%$ & $0.72 \%$ & $0.70 \%$ \\
\hline $\mathrm{CaO}$ & $0.016 \%$ & $0.025 \%$ & $0.012 \%$ \\
\hline $\mathrm{K}_{2} \mathrm{O}$ & $0.42 \%$ & $0.65 \%$ & $0.40 \%$ \\
\hline
\end{tabular}

The chemical analyses of the three composite grain size classes $<600 \mu \mathrm{m}->106 \mu \mathrm{m}$ of the three grades after washing compared to the calculated averages (Table 8) show obvious decrease of silicon, iron and calcium oxides, increase of potash and alumina contents of each of the three grades with no practical change of silica content of Grade III. This is referred to the exceptional high content of the grain size classes $>600 \mu$ in some samples of each of both grades I (samples No. 12, 13) and II (sample No. 14). In consequence, detailed grid pattern of sampling is recommended before exploitation. The sharp decrease of iron oxide and $\mathrm{CaO}$ contents of the three grades I, II, III after washing (times $0.39,0.32,0.18$ and 0.46, $0.35,0.016$ respectively, Table 9) can be considered valuable the studied silica sand to conform to the standard values (Table 10) and to be suitable approach for upgrading.

\section{MULTI MIN EGYPT FOR MINING}

\section{SGS MINERALS}

Table 10 - Standard values of Chemical Specifications

\begin{tabular}{|c|c|c|c|c|c|c|c|}
\hline \multirow{2}{*}{$\begin{array}{c}\text { Chemical } \\
\text { Specifications }\end{array}$} & \multicolumn{7}{|c|}{ Chemical Analysis } \\
\cline { 2 - 8 } & $\mathrm{SiO}_{2}$ & $\mathrm{Al}_{2} \mathrm{O}_{3}$ & $\mathrm{Fe}_{2} \mathrm{O}_{3}$ & $\mathrm{CaO}$ & $\mathrm{MgO}$ & L.O.I & Moisture \\
\hline Type no.(1) & 99.59 & 0.153 & 0.012 & 0.022 & 0.003 & 0.16 & 0.03 \\
\hline Type no.(2) & 99.59 & 0.3 & 0.018 & 0.021 & 0.003 & 0.16 & 0.03 \\
\hline Type no.(3) & 99.42 & 0.5 & 0.035 & 0.027 & 0.003 & 0.23 & 0.03 \\
\hline
\end{tabular}

\section{ECONOMIC POTENTIAL AND CONCLUSIONS}

The sand beds of white color 3-20 m thick cover an area extending from longitudes $29^{\circ} 22^{\prime \prime} 30^{\prime \prime}$ to $29^{\circ} 00^{\prime \prime} 00^{\prime \prime} \mathrm{E}$ and attaining its maximum thickness at Monqar El-Sanab - Monqar El-Raml area. Its area reaches about 120 million cubic meters which equal about 204 million tons. These figures point to the economic potential of the area between Gebel Hegif in the east and Dir El-Ressiw. Different grades of silica sand are usually not interchangeable in use, the present investigation studied in detail a combination of factors. These are geologic features, chemical constituents, grain size distribution, deleterious mineral impurities and physical properties of the silica sand beds exposed in Monqar El-Sanab - Monqar El-Raml. area at which these beds attain its maximum thickness $(20 \mathrm{~m})$ to evaluate the suitability of these silica sand beds and probable upgrading to conform to standard specifications for glassmaking, industrial, horticultural, leisure and foundry casting applications. The investigation reached to the following conclusions: -

1-The consolidated and very compact ferruginous sandstones comprise calcareous quartz arenite and ferruginous calcareous quartz arenite. Both consist chiefly of $>90 \%$ quartz $\left(\mathrm{SiO}_{2}>95\right.$ wt. \%), fine to coarse, rounded to sub-angular occasionally fractured grains. Magnetite, rutile, zircon, glauconite, hematite, staurolite, olivine and no chromite are recorded in both microfacies. These opaque minerals are not recorded in the silica sand beds.

2-The $\mathrm{SiO}_{2}$ content discriminates the silica sand into three Grades: $\mathrm{I}>98$, II $<98$ - > 97, III $<97->95$ wt. $\%$ and as well contents of $\mathrm{Al}_{2} \mathrm{O}_{3}: 0.35-0.14,1.71-0.3 ; 0.8-0.2,2.3-1.71$; and $\mathrm{Fe}_{2} \mathrm{O}_{3}: 1.84-0.4,2.3-$ 1.71 wt. $\%$. 


\section{Hassaan, et al}

3-The 3 grades record highest weight percentage of the size $<600 \mu \mathrm{m}->106 \mu \mathrm{m}$ to be considered suitable for upgrading the sand. Exceptional samples of Grades I, II exist where the sizes $>600 \mu \mathrm{m}$ possess high wt. \% to recommend combination of these size classes $>600 \mu \mathrm{m}$ of the sand from the sites of such samples on exploitation.

4-The washing of the sizes $<600 \mu \mathrm{m}->106 \mu \mathrm{m}$ produced sharp decrease of $\mathrm{Fe}_{2} \mathrm{O}_{3}, \mathrm{CaO}$ contents of the three grades (times $0.39,0.32,0.18$ and $0.46,0.35,0.016$ ).

5 -Loss on washing with water is $6.4,1.8,16.0 \mathrm{~kg} /$ ton and with 2 and $5 \% \mathrm{HCl}$ solution $6.4,1.8,16.0 \mathrm{~kg} / \mathrm{ton}$ to be considered an approach of suitable upgrading.

In consequence, the silica sand beds exposed in Qarat Somarah region are promising target to be recommended for detailed exploration and application of some form of processing techniques.

\section{REFERENCES}

Abu.Zeid, K (1984): Contribution to the geology of Wadi El Natrun area and its surroundings. M. Sc. Thesis, Cairo Univ.

Abu Khadrah, A. (1973): Geological and sedimentological studies of wadi El Natrun District, Western Desert, Egypt. Ph. D. Thesis, Cairo Univ.

Conco Coral and The Egyptian General Petroleum Corporation (1987): Geological map of Egypt $(1: 500,000)$ Cairo, Egypt.

EGSMA, (1998): Building Materials Map of Egypt, The Egyptian Geological Survey and Mining Authority and Academy of Scientific Research and Technology of Egypt, 1998.

EL Khoriby, E. M., (2004): Mechanism and Factors Affecting on the Petrification of the Wood Forest, North Moghra Oasis,Western Desert, Egypt. GEOCHEMISTRY 2004 ABSTRACTS. $6^{\text {th }}$ Inter. Conf. Geoch., Alex. Univ. Geology Dept., Alexandria, 2004, 91.

Hassaan, M. M., Ramzy, O. E., Sakr, S. M., Ali, H. I. (2019): On Geologic Features of the Early Miocene Moghra Formation and Probable Impact of Eastwards Progressive Propagation of West Gondwana Fragmentation Phases, Qarat Somarah Region, Northern Western Desert, Egypt, Ann. Geol. Surv. Egypt. XXXVI, 65 -95.

Issawi, B. El Hinnawi, M. Francis, M. and Mazhar, A., (1999): The Phanerozoic geology of Egypt. A geodynamic approach. The Egypt. Geol. Surv., Cairo, 462 p.

Issawi, B. El Hinnawi, M. Francis, M., Youssef, A. E.,Osman, R. A., (2009): The Phanerozoic geology of Egypt. A geodynamic approach. The Egypt. Geol. Surv., Cairo, 589 p.

Omara, S. M. and Sanad, S., (1975): Rock stratigraphy and structural Features of the area between wadi El Natrun and Moghra depression (western Desert), Egypt. Geol. Jb., 16. 45-73, Hannover.

Said, R., (1962): The geology of Egypt. Elsevier Press. Amsterdam. 370p.

Shata, A. (1955): An introductory note on the geology of the northern portion of the western Desert. Inst. Desert Egypt Bull., 5. 71-81.

Sigaev, N. A. (1959): The main tectonic features of Egypt. Geol. Survey of Egypt, Paper No. 1-26; Cairo. 
Monqar El Sanab-Monqar El Raml silica sand, Qarat Somarah region

\section{رمل سيليكا منقار الصنب - منقار الرمل ، منطقة قارة سومارة ، مصر: الاحتمالية الاقتصادية ويعض تقنيات المعالجة. \\ محمود حسان - هيثم على - أسامة رمزي - سيد صقر \\ ا-كلية العلوم -جامعة الازهر ب-شركة أسكوم للتعدين .مصر ب- جامعة طيبة. المدينة المنورة \\ الخلاصة}

تقع منطقة منقار الصنب - منقار الرمل على بعد .0 كم جنوب غرب مدينه الحمام التي تقع بشمال صحراء مصر الغربية. تضمن التتابع الصخري المركب للمتكون المغرة التابع للمايوسين المبكر حجر رملي حديدي شديد التماسك وطبقات متبادلة من رمل حديدي مفكلك ورمل سيليكا جيري وطفلة حديدية ثم طبقة رمل سيليكا ابيض ذات سمك . . متز وطبقة طفلة حديدية. ويعتبر رمل السيليكا أساسي لصناعات عديدة ذات جدوى اقتصادية عظيمة حيث هدفت الدراسة البي إجراء دراسات حقلية وبتروجرافية وكذا دراسات فيزيقوكيمائية وتوزيع الحجم الحبيبي وعمليات غسيل للرمال بمنطقة تشغل • rا مليون منز مكعب تزن ع • م مليون طن تقع ب قارة سومارة. وخلصت الدراسات الى احتمالية اقتصادية عظيمة الجدوى لرمال السيليكا البيضاء وكذا رفع الجودة بناء على مايلى :-

ا- الحجر الرملي المتماسك وشديد التماسك تميز الى سحنتي الارنيت الجيري والارنيت الحديدي الجيري يتكون كلاهما من • 9 \% كوارتز (أكسيد سيليكون 9\%\%) متوسط الحجم مستدير - شبة مستدير واحيانا تظهر به شروخ كما تحتوى على المعادن الثقيلة ماجنتيت - روتيل - زيركون - جلوكونيت - هيماتيت - شتوروليت - اولوفين ودون تسجيل كروميت في كل من النوعين

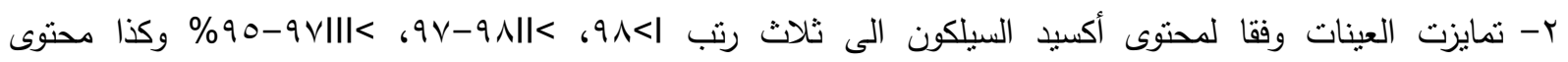

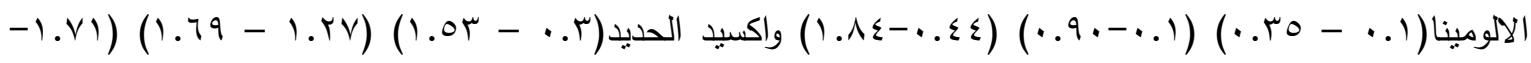
$\cdot($ r.r. r- سجل الحجم الحبيبي اقل من · . 7 ملى ميكرون الى اكبر من ج • 1 ملى ميكرون بالعينات الرتب الثلاثة مما يودى الى اعتبرها مناسبة الى اجراء تجارب لرفع الجودة ، توجد عينتين تتمثل في الرتبة الأولى وعينة واحدة تمتل الرتبة الثانية يجب اخذها في الاعتبار عند تحضير عينات مجمعة في الصناعة . ع- نتج عن غسيل الحجم الحبيبي الغالب بالرتب الثنلاثة نقصان حاد في نسبة أكا سبد الحديد والكالسيوم. ه- حقق الغسيل بالماء وكذا حمض الهيدروليك المخفف الى نقص الى ع.7 \&.1. 1 \&.7 1 كجم/طن مما يمكن اعتبارها اقتراب مناسب لرفع الجودة.

بناء على ذللك تحبذ نتائج الدراسة اجراء استكثاف جيولوجي وجيوكيميائى تفصيلي وكذا استخدام بعض أنواع تقنيات معالجة. طبقات رمل السيليكا المكثوفة بمنطقة قارة سومارة. التي تقع بإقليم شمال صحراء مصر الغربية. 